\title{
Strategi Pengembangan Kompetensi Guru Sekolah Dasar Negeri 22 Kabupaten Maros
}

\section{Development Strategies of Teacher Competencies in Public Elementary School 22 Maros Regency}

\author{
A. Nurdiyanti Idris ${ }^{1}$, Muhammad Yunus ${ }^{2}$, Asdar ${ }^{2}$ \\ ${ }^{1}$ Program Studi Pendidikan Guru sekolah Dasar, Universitas Maros \\ 2Program Studi Studi Pendidikan Dasar, Program Pascasarjana, Universitas Bosowa
}

E-mail: a_nurdiyawantiidris13@gmail.com

Diterima: 16 Juli 2020/Disetujui 07 Desember 2020

\begin{abstract}
Abstrak. Penelitian ini bertujuan untuk mengetahui, menganalisis dan menginterprestasi (1) Kompetensi guru di SDN 22 Kabupaten Maros, dan (2) Strategi pengembangan kompetensi guru di SDN 22 Kabupaten Maros. Penelitian ini bersifat deskriptif analisis dengan menggunakan pendekatan kualitatif. Penelitian ini dilakukan di SDN 22 Kabupaten Maros. Subjek penelitian ini adalah kepala sekolah dan guru di SDN 22 Kabupaten Maros. Data dikumpul melalui dokumentasi dan wawancara. Data dianalisis melalui tahap reduksi data, penyajian data, dan kesimpulan. Hasil penelitian menunjukkan bahwa hasil rekapitulasi penilaian kinerja guru di SDN 22 Maros selama tahun 2017-2018 dari jumlah guru sebanyak empat belas orang menunjukkan bahwa pada (1) kompetensi pedagogik, semua guru masuk dalam kategori tinggi. (2) kompetensi kepribadian, semua guru masuk dalam kategori tinggi. (3) Kompetensi sosial, terdapat delapan guru yang telah masuk dalam kategori tinggi dan enam guru yang masuk dalam kategori sedang. (4) Kompetensi profesional, terdapat sepuluh guru yang telah masuk dalam kategori tinggi dan empat guru yang masuk dalam kategori sedang. Strategi yang digunakan kepala sekolah SDN 22 Maros dalam mengembangkan kompetensi guru adalah kegiatan Supervisi khusus, Kelompok Kerja Guru (KKG) dan Pendidikan Pelatihan (Diklat).
\end{abstract}

Kata Kunci: Kompetensi Guru, Strategi Pengembangan, SD, Maros

\begin{abstract}
This study aims to determine, analyze and interpret: (1) Teacher competencies in SDN 22 Maros Regency; and (2) Development strategies of teacher competencies in SDN 22 Maros Regency. This research is a descriptive analysis using a qualitative approach. This research was conducted at SDN 22 Maros Regency. The subjects of this study were the principal and teachers at SDN 22 Maros Regency. Data collected through documentation and interviews. Data were analyzed through data reduction, data presentation, and conclusion stages. The results showed that the recapitulation of teacher performance appraisal at SDN 22 Maros during 2017-2018 from a total of fourteen teachers showed that in: (1) pedagogical competence, all teachers are in the high category; (2) personality competence, all teachers are in the high category; (3) social competence, there are eight teachers who have been included in the high category and six teachers who are in the medium category; (4) Professional competence, there are ten teachers who have been included in the high category and four teachers who are in the medium category. The strategy used by the principal of Public Elementary School 22 Maros Regency in developing teacher competencies is through Special Supervision, Teacher Working Group (KKG) and Training Education (Diklat) activities.
\end{abstract}

Keywords: Teacher Competencies, Development Strategies, Elementary School, Maros

\section{Pendahuluan}

Guru merupakan salah satu komponen penting dalam dunia pendidikan untuk mencapai tujuan pendidikan. Hal itu karena guru adalah ujung tombak pendidikan sebab guru secara langsung berupaya memengaruhi, membina dan mengembangkan kemampuan siswa agar menjadi manusia yang cerdas, terampil, dan bermoral tinggi. Guru dituntut untuk memiliki kemampuan yang diperlukan sebagai pendidik dan pengajar. Sebagai pengajar, guru dituntut harus menguasai bahan ajar yang diajarkan dan terampil dalam mengajarkannya. Dalam proses pembelajaran, penguasaan materi pelajaran dan cara menyampaikannya merupakan syarat yang sangat essensial.

Undang-undang RI Nomor 14 tahun 2005 tentang Guru dan Dosen Pasal 7 ayat 1 menyebutkan bahwa Guru adalah pendidik professional dengan tugas utama mendidik, mengajar, membimbing, mengarahkan, melatih, menilai, dan mengevaluasi peserta didik pada pendidikan anak usia dini, jalur pendidikan formal, pendidikan dasar dan pendidikan menengah. Dan Undang-undang RI No. 20 tahun 2003 tentang Sistem Pendidikan Nasional Pasal 39 ayat 2 menyebutkan Pendidik merupakan tenaga profesional yang bertugas merencanakan dan melaksanakan proses pembelajaran, menilai hasil pembelajaran, melakukan pembimbingan dan pelatihan serta melakukan penelitian dan pengabdian kepada masyarakat, terutama bagi pendidik pada perguruan tinggi. 
Guru wajib memiliki keahlian yang memadai untuk menjalankan tugasnya sebagai pendidik. Undang-undang RI Nomor 14 tahun 2005 tentang Guru dan Dosen Pasal 8 menyebutkan bahwa guru wajib memiliki kualifikasi akademik, kompetensi, sertifikasi pendidikan, sehat jasmani dan rohani serta memiliki kemampuan untuk mewujudkan tujuan nasional. Lebih lanjut lagi, dalam Pasal 10 ayat 1 dinyatakan bahwa kompetensi guru sebagaimana dimaksud dalam Pasal 8 meliputi kompetensi pedagogik, kompetensi kepribadian, kompetensi sosial, dan kompetensi profesional yang diperoleh melalui pendidikan profesi.

Kompetensi pedagogik merupakan kompetensi yang secara khas mencirikan dan membedakan profesi guru dengan profesi lainnya. Penguasaan terhadap teori perkembangan dan teori-teori belajar mutlak ada pada guru. Oleh kerena itu, perlu ditumbuhkan kesadaran terhadap penguasaan materi, perkembangan peserta didik, teori-teori balajar, pengembangan kurikulum, teknik evaluasi, penguasaan terhadap model-modell dan metode pengajaran. Semuanya itu perlu, di samping penguasaan terhadap mata pelajaran dan iptek yang berkaitan dengan pengajaran (Nur, 2014). Kompetensi kepribadian mensyaratkan bahwa guru harus berperan sebagai pendidik yang dapat mempengaruhi proses belajar mengajar kearah proses sesuai dengan tata nilai yang dianggap baik dan berlaku dalam masyarakat. Guru harus mampu membelajarkan siswa tentang disiplin diri, membaca, memahami aturan, mencintai buku, bagaimana cara mengajar, menghargai waktu, dan belajar bagaimana harus berbuat. Kompetensi sosial, merupakan kemampuan guru untuk berkomunikasi dan bergaul secara efektif dengan peserta didik, tenaga kependidikan, orang tua/wali peserta didik, dan masyarakat sekitar. Kompetensi ini terefleksi dengan kemampuan berkomunikasi lisan dan tulisan, mampu menggunakan teknologi komunikasi dan informasi secara fungsional, cakap bergaul secara efektif dengan peserta didik, sesama pendidik, tenaga kependidikan, orang tua/wali peserta didik, cakap bergaul secara santun dengan masyarakat sekitar (Susilowati et al, 2013). Kompetensi profesional adalah kemampuan pendidik dalam penguasaan materi pembelajaran secara luas dan mendalam yang memungkinkannya membimbing peserta didik memperoleh kompetensi yang ditetapkan (Suhandani \& Julia, 2014).

Kompetensi guru diperlukan dalam rangka mengembangkan dan mendemonstrasikan perilaku pendidikan, bukan sekedar mempelajari keterampilan-keterampilan mengajar tertentu tetapi merupakan penggabungan dan aplikasi suatu keterampilan dan pengetahuan yang saling bertautan dalam bentuk perilaku nyata (Jainuddin, 2019). Menurut Majid dalam Andriani (2014) mendefinisikan bahwa standar kompetensi guru adalah suatu ukuran yang ditetapkan atau dipersyaratkan dalam bentuk penguasaan pengetahuan dan berperilku layaknya seorang guru untuk menduduki jabatan fungsional sesuai bidang tugas, kualifikasi, dan jenjang pendidikan. Sedangkan pendapat lain yaitu dari Asmani (2009) guru adalah figur teladan yang diikuti anak didik dan menjadi cermin masyarakat. Sebagai pendidik yang profesional, guru bukan saja dituntut melaksanakan tugasnya secara profesional, tetapi juga memiliki pengetahuan dan kemampuan profesional. Guru harus menempatkan diri dan menciptakan suasana kondusif, karena fungsi guru di sekolah sebagai bapak kedua yang bertanggung jawab atas pertumbuhan dan perkembangan jiwa anak (Sutikno, 2013).

Strategi merupakan suatu rencana yang digunakan untuk mencapai tujuan yang ditetapkan sebelumnya. Menurut Wena (2010), strategi adalah cara atau seni menggunakan sumber daya untuk mencapai tujuan tertentu. Sehubungan dengan pengertian strategi tersebut, berbagai upaya pengembangan kompetensi guru telah dilakukan oleh pemerintah, yaitu dengan mengesahkan Undang-undang No. 14 tahun 2005 tentang Guru dan Dosen yang diikuti dengan terbitnya Peraturan Menteri Akademik dan Kompetensi Guru (Nomor 16), dan Sertifikasi Bagi Guru dalam Jabatan (Nomor 18).

Keberadaan guru yang profesional bagi suatu bangsa amatlah penting, apalagi bagi suatu bangsa yang sedang berkembang untuk membangun, terlebih bagi keberlangsungan hidup bangsa di tengah-tengah lintasan perjalanan zaman dengan teknologi yang kian canggih dan segala perubahan serta pergeseran nilai yang cenderung memberi nuansa kepada kehidupan yang menuntut ilmu dan seni dalam kadar dinamika untuk dapat mengadaptasikan diri (Usman dalam Noor: 2015). Pengembangan ini dapat dilakukan melalui upaya-upaya strategis, baik oleh pemerintah, sekolah, maupun oleh guru yang bersangkutan (Jainuddin \& Sirajuddin).

Fenomena mutu pendidikan di Indonesia sangat rendah. Salah satu faktor yang berkaitan dengan hal ini tentunya kemampuan guru dalam melaksanakan pembelajaran. Kurangnya penerapan strategi yang menyebabkan beberapa kompetensi guru tidak terlaksana sehingga kompetensi guru perlu dikembangkan disetiap sekolah, termasuk di SDN 22 Maros yang berada diwilayah Kecamatan Maros Baru Kabupaten Maros. Kepala sekolah SDN 22 Maros ini senantiasa mengembangkan kompetensi guru-gurunya. Kepala sekolah terus berupaya mengembangkan berbagai strategi untuk meningkatkan kinerja guru-guru disekolah tersebut. Berdasarkan data observasi yang telah diperoleh, kinerja guru disekolah tersebut rata-rata memperoleh nilai 4 (empat) dengan kategori amat baik. Hal ini tidak terlepas dari berbagai upaya kepala sekolah dalam mengembangkan kompetensi guru disekolah tersebut.

Pengembangan kompetensi guru sangat penting dalam dunia pendidikan. Hal ini menarik perhatian peneliti untuk menganalisis strategi pengembangan yang diterapkan oleh kepala sekolah di SDN 22 Maros. Penelitian ini bertujuan untuk mengetahui, menganalisis dan menginterprestasi (1) Kompetensi guru di SDN 22 Kabupaten Maros, dan (2) Strategi pengembangan kompetensi guru di SDN 22 Kabupaten Maros.

\section{Metode Penelitian}

Penelitian ini adalah penelitian deskriptif kualitatif. Penelitian deskriptif kualitatif sebagaimana yang diungkapkan Sugiyono (2012) penelitian kualitatif sebagai metode penelitian yang berlandaskan pada filsafat postpositivisme, digunakan untuk meneliti pada kondisi objek alamiah, dimana peneliti adalah sebagai instrumen kunci, teknik pengumpulan data dengan triangulasi, analisis data bersifat induktif atau kualitatif, dan hasil penelitian kualitatif lebih menekankan makna daripada generalisasi. Sedangkan menurut Sukmadinata (2011), penelitian deskriptif kualitatif ditujukan untuk mendeskripsikan dan menggambarkan fenomena-fenomena yang ada, baik bersifat alamiah maupun rekayasa manusia, yang 
lebih memperhatikan mengenai karakteristik, kualitas, keterkaitan antar kegiatan. Penelitian ini dilaksanakan di SDN 22 Maros dengan tujuan ingin menganalisis strategi pengembangan kompetensi guru berdasarkan penilaian kinerja guru di sekolah ini.

Teknik yang digunakan dalam pengumpulan data dalam penelitian ini adalah dokumentasi dan wawancara. Penelitian ini menggunakan metode dokumentasi untuk mencari data tentang penilaian kinerja guru di SDN 22 Maros dan wawancara dengan kepala sekolah dan guru menyangkut strategi kepala sekolah dalam mengembangkan kompetensi guru yang terdiri dari kompetensi pedagogik, kompetensi kepribadian, kompetensi sosial, dan kompetensi profesional.

Teknik analisis data yang digunakan oleh penulis adalah reduksi data, penyajian data dan kesimpulan serta pengabsahan data yang digunakan dengan cara triangulasi dan membercheck.

\section{Hasil dan Pembahasan}

\section{Kompetensi Guru di SDN 22 Kabupaten Maros.}

Hasil penelitian dari rekapitulasi penilaian kinerja guru yang terdiri dari empat kompetensi guru (aspek pendagogik, aspek kepribadian, aspek professional, dan aspek sosial) di SDN 22 Maros Kecamatan Maros Baru Kabupaten Maros, dengan jumlah guru sebanyak 14 orang. Hal tersebut dapat diuraikan sebagai berikut:

1. Kompetensi Pedagogik

Berdasarkan hasil rekapitulasi kinerja guru pada kompetensi pedagogik di atas menunjukkan bahwa dari jumlah keseluruhan guru yaitu 14 orang, semuanya tergolong dalam kategori tinggi. Dalam hal ini perlu adanya peningkatan pembinaan pada kompetensi pedagogik agar kinerja guru meningkat.

2. Kompetensi Kepribadian

Berdasarkan hasil rekapitulasi kinerja guru pada kompetensi kepribadian menunjukkan bahwa dari jumlah keseluruhan guru yaitu 14 orang, semuanya tergolong dalam kategori tinggi. Dalam hal iniguru telah memahami dan melaksanakan kompetensi kepribadian dengan baik.

3. Kompetensi Sosial

Berdasarkan hasil rekapitulasi kinerja guru pada kompetensi sosial menunjukkan bahwa dari jumlah keseluruhan guru yaitu 14 orang, terdapat 8 guru yang tergolong dalam kategori tinggi dan 6 guru tergolong dalam kategori sedang. Dalam hal ini perlu adanya pembinaan pada kompetensi sosial agar kinerja guru meningkat.

4. Kompetensi Profesional

Berdasarkan hasil rekapitulasi kinerja guru pada kompetensi professional di atas menunjukkan bahwa dari jumlah keseluruhan guru yaitu 14 orang, terdapat 10 guru yang tergolong dalam kategori tinggi dan 4 guru tergolong dalam kategori sedang. Dalam hal ini perlu adanya peningkatan pembinaan pada kompetensi profesional agar kinerja guru meningkat.

Strategi Pengembangan Kompetensi Guru di SDN 22 Kabupaten Maros

SDN 22 Maros menerapkan berbagai strategi dalam upaya mengembangkan kompetensi yang dimiliki oleh setiap guru. Pengembangan kompetensi guru dilakukan oleh kepala sekolah melalui tiga kegiatan strategi yakni Supervisi, Kelompok Kerja Guru (KKG), dan Pendidikan Pelatihan (Diklat). Berikut ini:

\section{Supervisi}

Strategi yang diterapkan oleh kepala sekolah di SDN 22 Maros dalam mengembangkan kompetensi guru adalah supervisi khusus (supervisi mini), melalui kegiatan supervisi mini yang dapat meningkatkan kualitas guru dalam proses pembelajaran dengan tujuan untuk meningkatkan kualitas belajar siswa yang dimulai dari perencanaan pembelajaran, pelaksanaan kegiatan pembelajaran, mengevaluasi pembelajaran sampai melakukan refleksi. Selain itu, untuk meningkatkan kualitas pembelajaran supervisi juga bertujuan untuk pengembangan sumber daya guru. Kegiatan ini dapat membantu guru dalam penguasaan materi pembelajaran secara luas dan mendalam yang memungkinkan pembimbingan peserta didik memenuhi standar kompetensi yang ditetapkan dalam Standar Pendidikan Nasional.

\section{Kelompok Kerja Guru (KKG)}

Strategi kedua yang diterapkan oleh kepala sekolah di SDN 22 Maros dalam mengembangkan kompetensi guru adalah mengikutsertakan guru dalam kegiatan KKG. kegiatan KKG ini dapat membantu guru dalam menggali informasi atau mencari solusi dari permasalahan pembelajaran yang didapatkan dikelas, dan kegiatan KKG guru juga dibekali dengan berbagai keterampilan dalam pengembangan kopetensi guru sesuai dengan Standar Pendidikan Nasional yang dapat berpengaruh terhadap peningkatan kinerjanya.

3. Pendidikan Dan Pelatihan (Diklat)

Strategi ketiga yang diterapkan oleh kepala sekolah di SDN 22 Maros dalam mengembangkan kompetensi guru adalah yaitu mengikutsertakan guru dalam kegiatan pendidikan dan pelatihan (diklat). Dalam kegiatan ini, guru di latih dalam membahas kurikulum seperti menyusun silabus, membuat RPP, merancang media pembelajaran dan sebagainya. Pelaksanaan dalam kegiatan diklat ini, ada waktu tertentu seperti halnya pembagian guru yang berhak mengikuti kegiatan diklat. Biasanya dilaksanakan saat adanya masalah baru yang perlu dibahas seperti kurikulum 2013. Masih ada beberapa kelas dari setiap sekolah di Kecamatan maupun Kabupaten yang belum menerapkan K 13, sehingga guru-gurunya belum memahami K 13. Oleh karena itu, guru yang mengikuti kegiatan diklat ini tidak bisa ditentukan jumlahnya dan melalui kegiatan diklat ini maka kompetensi guru akan meningkat. 
Kompetensi Guru di SDN 22 Kabupaten Maros.

1. Kompetensi Pedagogik

Hasil rekapitulasi penilaian kinerja guru pada kompetensi pedagogik menunjukkan bahwa dari 14 jumlah guru yang nilainya tergolong dalam kategori tinggi dengan interval nilai 22-28, telah melaksanakan kompetensi pedagogik dengan baik seperti guru mampu mengembangkan kurikulum/silabus pendidikan nasional yang disesuaikan dengan kondisi spesifik lingkungan sekolah dengan memperhatikan kebutuhan dan nilai yang berlaku di masyarakat. Pada aspek penguasaan karakteristik peserta didik, guru dapat mengatur kelas untuk memberikan kesempatan belajar yang sama pada semua peserta didik dengan kelainan fisik dan kemampuan belajar yang berbeda, hal itu membantu proses pembelajaran terkait aspek fisik, intelektual, sosial, emosional, moral, dan latar belakang sosial budaya. Pada aspek penguasaan teori belajar yang mendidik, guru mampu menetapkan berbagai pendekatan, strategi dan teknik pembelajaran yang mendidik secara kreatif sesuai dengan standar kompetensi guru, hal ini membantu peningkatan pemahaman peserta didik terhadap materi pembelajaran. Pada aspek pengembangan potensi peserta didik, guru mampu menganalisis potensi peserta didik yang berbeda-beda melalui program pembelajaran yang mengaktualisasikan potensi akademik dan non akademik. Pada aspek penilaian dan evaluasi, guru mampu mengevaluasi pembelajaran yang dilakukan meliputi perencanaan, respon siswa, hasil belajar, metode dan pendekatan yang digunakan. Seorang guru dapat merencanakan penilaian yang tepat dengan melakukan pengukuran dengan benar dan membuat kesimpulan dan solusi yang akurat. Pada aspek penguasaan teori belajar dan prinsip-prinsip belajar yang mendidik, guru telah mampu menciptakan suasana belajar yang menyenangkan bagi peserta didik, guru telah memahami teori belajar yang dapat meningkatkan semangat belajar peserta didik seperti dengan menggunakan multimedia dalam proses pembelajaran. Hal ini sejalan dengan pendapat Mulyasa, (2008: 75) menjelaskan pengertian dari kompetensi pedagogik guru adalah kemampuan mengelola pembelajaran peserta didik yang meliputi pemahaman terhadap peserta didik, perancangan dan pelaksanaan pembelajaran, evaluasi hasil belajar dan pengembangan peserta didik untuk mengaktualisasikan berbagai potensi yang dimilikinya.

\section{Kompetensi Kepribadian}

Hasil rekapitulasi penilaian kinerja guru pada kompetensi kepribadian menunjukkan bahwa dari 14 jumlah guru yang nilainya tergolong dalam kategori tinggi dengan interval nilai 10-12 dan sedang dengan interval nilai 7-9. Semua guru pada kompetensi ini masuk dalam kategori tinggi. Hal ini dapat dilihat berdasarkan dari ketiga aspek kepribadian yaitu bertindak sesuai dengan norma agama, hukum, sosial, dan budaya guru mampu menjadi contoh dan teladan bagi peserta didik karena peserta didik cenderung mencontoh perilaku gurunya. Perilaku apa saja yang dilakukan oleh guru maka peserta didik akan menirunya. Guru telah memiliki tanggung jawab yang tinggi seperti kedisiplinan dalam mengawali mengakhiri pembelajaran dengan tepat waktu sesuai jadwal yang telah ditetapkan. Hal tersebut sejalan dengan pendapat Suyatno (2008: 16) kepribadian yang berwibawa dapat ditunjukkan melalui perilaku yang berpengaruh positif bagi peserta didik dan memiliki perilaku yang disegani. Akhlak mulia dan teladan dapat dilihat melalui tindakan yang dilakukan sesuai dengan norma agama (iman dan taqwa, jujurm ikhlas, suka menolong), dan memiliki perilaku yang bisa diteladani oleh peserta didik.

3. Kompetensi Sosial

Hasil rekapitulasi penilaian kinerja guru pada kompetensi sosial menunjukkan bahwa dari 14 jumlah guru yang nilainya tergolong dalam kategori tinggi dengan interval nilai 7-8 dan sedang dengan interval nilai 5-6. Guru yang nilainya tergolong dalam kategori tinggi telah melaksanakan kompetensi sosial dengan baik seperti pada aspek komunikasi dengan sesama guru, tenaga kependidikan, orang tua peserta didik, guru mampu menjaga silaturahmi utamanya terhadap orang tua peserta didik, guru mampu berkomunikasi secara efektif dan empatik sehingga terjalin kerjasama yang baik dengan orang tua peserta didik. Sebagaimana dikatakan dalam Permendiknas No. 16 tahun 2007 bahwa guru harus berkomunikasi secara efektif, empatik, dan santun dengan sesama pendidik, tenaga kependidikan, orang tua, dan masyarakat, meliputi: (a) berkomunikasi dengan teman sejawat dan komunitas ilmiah lainnya secara santun, empatik dan efektif, (b) berkomunikasi dengan orang tua peserta didik dan masyarakat secara santun, empatik, dan efektif tentang program pembelajaran dan kemajuan peserta didik, (c) mengikutsertakan orang tua peserta didik dan masyarakat dalam program pembelajaran dan dalam mengatasi kesulitan belajar peserta didik.

Di sisi lain, perlu adanya peningkatan pembinaan kompetensi sosial agar dapat meningkatkan kinerja guru dikarenakan masih terdapat beberapa guru yang masuk dalam kategori sedang. Hal tersebut disebabkan adanya kendala yang dialami guru seperti bersikap inklusif, bertindak objektif, serta tidak diskriminatif masih ada beberapa guru yang melakukan tindakan deskriminatif kepada peserta didik seperti guru lebih cenderung memerhatikan peserta didik yang pandai dalam proses belajar mengajar atau berasal dari daerah yang sama dengan guru, faktor itu yang membuat guru berlaku tidak adil kepada peserta didik. Hal ini tidak sesuai dengan Permendiknas No. 16 tahun 2007, Guru harus bersikap inklusif dan objektif terhadap peserta didik, teman sejawat dan lingkungan sekitar dalam melaksanakan pembelajaran serta tidak bersikap diskriminatif terhadap peserta didik, teman sejawat, orang tua peserta didik dan lingkungan sekolah karena perbedaan agama, suku, jenis kelamin, latar belakang keluarga, dan status sosial-ekonomi.

Berdasarkan uraian diatas, terkait dengan guru yang nilainya masuk pada kategori sedang dalam kompetensi sosial, guru harus menunjukkan sikap yang tidak deskriminatif dengan tidak membedakan peserta didik satu sama lain baik itu kondisi fisik, intelektual, maupun tempat tinggal.

4. Kompetensi Profesional

Hasil rekapitulasi penilaian kinerja guru pada kompetensi profesional menunjukkan bahwa dari 14 jumlah guru yang nilainya tergolong dalam kategori tinggi dengan interval nilai 7-8 dan sedang dengan interval nilai 5-6. Guru yang nilainya tergolong dalam kategori tinggi telah mampu mengembangkan keprofesionalan melalui tindakan yang reflektif seperti guru telah belajar dari berbagai sumber dengan mengikuti pelatihan-pelatihan guna meningkatkan kinerja keprofesionalannya. Selain itu, di sisi lain perlu adanya peningkatan pembinaan kompetensi professional agar dapat meningkatkan kinerja guru 
dikarenakan masih terdapat beberapa guru yang masuk dalam kategori sedang. Hal tersebut disebabkan adanya kendala yang dialami guru seperti penguasaan materi, struktur, konsep dan pola pikir keilmuan yang mendukung mata pelajaran yang diampu, guru mengalami kerumitan dalam penyusunan materi ajar yang sesuai dengan struktur keilmuan, penyesuaian materi ajar terhadap peserta didik yang berbeda-beda, serta kurang maksimalnya guru dalam mengeksplor sumber materi ajar berupat internet. Hal ini tidak sesuai dengan Permendiknas No. 16 tahun 2007, Guru harus memahami penguasaan materi mata pelajaran yang diajarkan, memahami penguasaan struktur mata pelajaran yang diajarkan, memahami penguasaan konsep mata pelajaran yang diajarkan, dan memahami pola pikir keilmuan yang mendukung mata pelajaran yang diajarkan.

Berdasarkan uraian diatas, terkait dengan guru yang nilainya masuk pada kategori sedang dalam kompetensi professional pada penguasaan materi ajar perlu di kuasai oleh seorang guru agar proses belajar mengajar dapat terlaksana dengan baik, selain itu teknologi juga perlu dipelajari oleh guru sebab materi yang akan diberikan kepada peserta didik bukan hanya melalui buku-buku tetapi bisa diakses melalui internet.

\section{Strategi Pengembangan Kompetensi Guru di SDN 22 Kabupaten Maros}

1. Supervisi

Supervisi merupakan proses pembinaan yang dilakukan kepala sekolah kepada guru-gurunya dengan mendatangi setiap kelas untuk mengobservasi bagaimana guru mengajar atau bisa dikatakan kepala sekolah ingin melihat seperti apa kekurangan dan kelemahan guru yang perlu diperbaiki agar kinerjanya dapat meningkat. Kegiatan supervisi merupakan implementasi untuk meningkatkan kemampuan guru dalam mengembangkan keprofesionalan dengan memperbaiki dan meningkatkan proses pembelajaran yang dilakukan oleh kepala sekolah. Pengembangan kompetensi Pedagogik melalui kegiatan supervisi memberi pemahaman kepada guru bagaimana memahami karakter peserta didik, mengembangkan kurikulum dan kemampuan guru dalam membuat perangkat pembelajaran.

Pengembangan kompetensi kepribadian melalui kegiatan supervisi memberi gambaran pada guru agar lebih menunjukkan pribadi teladan yang dapat dijadikan panutan bagi peserta didik. Sebagaimana yang dikemukakan oleh Hidayatullah (2010: 43) bahwa ada tiga unsur agar seorang guru dapat diteladani atau menjadi teladan, yaitu (1) Kesiapan untuk dinilai dan dievaluasi berarti adanya kesiapan menjadi cermin baik untuk dirinya sendiri maupun untuk orang lain, (2) Memiliki kompetensi minimal atau memiliki ucapan, sikap, dan perilaku untuk diteladani, (3) Memiliki integritas moral merupakan adanya kesamaan antara apa yang diucapkan dan apa yang dilakukan. Selain itu, guru juga harus bertindak sesuai norma yang ada seperti norma agama, hukum, sosial, dan kebudayaan. Seorang guru juga harus mempunyai tanggung jawab dan etos kerja yang tinggi dalam mendidik peserta didik.

Pengembangan kompetensi profesional melalui kegiatan supervisi memberi gambaran pada guru mengenai penguasaan materi pelajaran, penguasaan professional keguruan dan pendidikan, penguasaan cara-cara menyesuaikan diri dan berkepribadian untuk menyelesaikan tugasnya. Sebagaimana dikatakan oleh Muchith dalam Shabir (2015: 230), Kompetensi profesional adalah seperangkat kemampuan dan keterampilan terhadap penguasaan materi pelajaran secara mendalam, utuh, dan komprehensif. Guru yang memiliki kompetensi professional tidak cukup hanya memiliki kemampuan terhadap materi ilmu lain yang memiliki keterkaitan dengan pokok bahasan mata pelajaran tertentu.

Pengembangan kompetensi sosial melalui kegiatan supervisi memberi gambaran pada guru mengenai kemampuan guru untuk berkomunikasi dan berinteraksi secara efektif dan efisien dengan peserta didik, sesama guru, orang tua/wali peserta didik, dan masyarakat sekitar. Sebagaimana dikatakan oleh Sadirman (2010) bahwa dalam proses komunikasi dikenal adanya unsur saluran. Jadi, unsur-unsur yang terlibat dalam komunikasi, pesan, dan saluran atau media. Begitu juga hubungan antara manusia yang satu dengan manusia yang lain, empat unsur untuk terjadinya proses komunikasi itu akan selalu ada.

2. Kelompok Kerja Guru (KKG)

Strategi kedua yang diterapkan oleh kepala sekolah SDN 22 Maros dalam mengembangkan kompetensi guru adalah melalui kegiatan Kelompok Kerja Guru (KKG). KKG merupakan wadah bagi guru untuk saling berbagi informasi tentang wawasan kependidikan serta sebagai tempat mencari solusi secara bersama atas permasalahan yang dihadapi selama proses belajar mengajar dikelas. Dalam kegiatan KKG ini guru membentuk kelompok kemudian membahas permasalahan secara bersama-sama. Pengembangan kompetensi pedagogik melalui kegiatan KKG memberi bekal pada guru agar guru lebih memahami peserta didik dengan berbagai karakteristik yang berbeda sehingga tidak ada lagi masalah yang dihadapi dalam proses pembelajaran. Selain itu, kompetensi pedagogik ini juga mempengaruhi KKG karena dengan kegiatan ini guru dapat merancang pembelajaran yang memanfaatkan teknologi dalam proses pembelajaran dan evaluasi hasil belajar.

Pengembangan kompetensi kepribadian melalui kegiatan KKG agar dapat membekali guru dalam berperilaku yang baik sehingga dapat dijadikan panutan bagi peserta didik. Guru merupakan panutan bagi peserta didik sehingga perilaku seorang guru harus tetap terjaga dengan memberikan contoh-contoh perilaku yang mencerminkan norma-norma yang berlaku dalam kehidupan masyarakat seperti norma agama, hukum, sosial, dan kebudayaan. Sebagaimana dikemukakan oleh Sanjaya (2008: 277-278), guru sering dianggap sebagai sosok yang memiliki kepribadian ideal. Oleh karena itu, pribadi guru sering dianggap sebagai model atau panutan (yang harus di-gugu dan di-tiru). Sebagai seorang model, guru harus memiliki kompetensi yang berhubungan dengan pengembangan kepribadian (personal competencies), di antaranya: (1) Kemampuan yang berhubungan dengan pengamalan ajaran agama sesuai dengan keyakinan agama yang dianutnya, (2) Kemampuan untuk menghormati dan menghargai antarumat beragama, (3) Kemampuan untuk berperilaku sesuai dengan norma, aturan dan sistem nilai yang berlaku di masyarakat, (4) Mengembangkan sifat-sifat terpuji sebagai seorang guru misalnya, sopan santun dan tata karma, (4) Bersifat demokratis dan terbuka terhadap pembaruan dan kritik. Melalui kegiatan Kelompok Kerja Guru (KKG) dapat memberi manfaat bagi guru dalam memantapkan kepribadian sebagai seorang pendidik. Sebagai seorang pendidik harus memiliki kepribadian mantap, stabil, dewasa, arif, dan berwibawa, menjadi teladan bagi peserta didik, dan berakhlak mulia. Diharapkan dengan adanya kegiatan Kelompok Kerja Guru (KKG) dapat memberikan manfaat berupa pemahaman dan 
penyadaran bahwa seorang guru harus memiliki kompetensi kepribadian yang baik, sehingga dapat menjadi teladan atau contoh bagi para peserta didik.

Kompetensi profesional guru memang harus ditingkatkan karena pada dasarnya kompetensi itu sangat penting. Dengan melalui KKG kewajiban sekolah dalam peningkatan kualitas guru dapat diwujudkan. Jadi sekolah tidak terlalu repot mengadakan berbagai macam pelatihan, cukup dengan mengutus gurunya mengikuti program KKG. Sebagaimana dikemukakan oleh Asmanii (2009) mengemukakan bahwa kompetensi professional guru harus terus dikembangkan untuk menunjang profesionalitas kerjanya terkait dengan pelaksanaan kegiatan belajar mengajar. Pengembangan kompetensi professional guru dapat membekali guru dalam menguasai teknik-teknik pembelajaran, dan juga melatih guru dalam penyusunan laporan penelitian maupun laporan karya ilmiah . selain itu guru juga dilatih dalam mempersiapkan alat peraga yang sesuai dengan materi ajar yang akan diberikan kepada peserta didik. Guru harus jeli menggunakan setiap alat peraga yang akan digunakan dalam PBM, sebab kalau tidak alat peraga bukanlah menambah efektivitas pembelajaran akan tetapi berpeluang menjadi sumber gangguan dalam pembelajaran. Disisi lain guru mungkin saja masih banyak yang tidak menggunakan alat peraga sebagai alat bantu belajar padalah hal itu sangat penting. Untuk itulah melalui KKG beberapa keterampilan dalam membuat alat peraga atau keterampilan lainnya dapat dipelajari.

Kompetensi sosial adalah kemampuan pendidik berkomunikasi dan berinteraksi secara efektif dengan peserta didik, sesama pendidik, tenaga kependidikan, orangtua/ wali peserta didik, dan masyarakat. Kegiatan Kelompok Kerja Guru (KKG) dapat menunjang kompetensi sosial. Hal guru dapat memahami seberapa pentingnya bersosial dengan lingkungan, masyarakat, teman sejawat dan lain sebagainya. Hal ini dikarenakan kegiatan KKG memberikan sosialisasi atau pembekalan materi mengenai tugas dan peran guru dalam kehidupan bersosial di lingkungan sekolah dan sekitarnya. Dengan adanya kegiatan KKG menjadikan wawasan guru semakin luas mengenai cara berkomunikasi dan berinteraksi. Kegiatan KKG juga mengajarkan guru cara berkomunikasi yang baik dengan siswa, sehingga dalam melaksanakan tugas utamanya dalam mengajar guru dapat menjelaskan dengan bahasa yang komunikatif dan mudah dipahami oleh para peserta didik.

3. Pendidikan Dan Pelatiahn (Diklat)

Strategi ketiga yang diterapkan oleh kepala sekolah SDN 22 Maros dalam mengembangkan kompetensi guru adalah melalui kegiatan Pendidikan dan Pelatihan (diklat). Diklat merupakan suatu kegiatan yang dilakukan untuk mengembangkan kualitas manusia utamanya guru melalui metode pengajaran dan pelatihan. Hubungan diklat dengan pengembangan profesi pendidik yaitu untuk meningkatkan kemampuan guru menjadi lebih professional sebagai seorang pendidik. Dalam kegiatan ini guru dilatih untuk mengembangkan kurikulum utamanya kurikulum 2013 yang belum dipahami oleh guru kelas secara merata. Guru kelas masih sulit memahami penerapan K 13 dalam proses belajar mengajar karena banyaknya kerumitan yang harus diselesaikan dalam penerapan K 13 ini mulai dari pengembangan kurikulum, silabus, dan lain sebagainya. Maka dari itu melalui kegiatan diklat ini guru berlatih semaksimal mungkin agar dapat meningkatkan kemampuannya.

Pengembangan kompetensi pedagogik melalui kegiatan diklat memberi bekal pada guru mengenai pengembangan kurikulum dan silabus. Guru berlatih membuat perangkat pembelajaran. Sebagaimana dikemukakan oleh Alsubaie (2016) menyatakan bahwa, berbagai studi telah menyatakan tingkat keterlibatan guru sebagai pusat pengembangan kurikulum menunjukkan pencapaian yang efektif dalam pembaruan kurikulum.oleh karena itu guru merupakan faktor penting dalam kesuksesan pengembangan kurikulum termasuk dalam langkah implikasi dan evaluasi.

Pengembangan kompetensi kepribadian melalui kegiatan diklat melatih guru dalam berperilaku baik dan menjadi panutan bagi peserta didik. Sebagaimana dikemukakan oleh Yahya (2013:59) kompetensi kepribadian guru adalah kemampuan personal seseorang yang mencerminkan kepribadian sebagai berikut: (a) mantap dan stabil artinya seseorang memiliki konsistensi dalam bertindak sesuai dengan norma hukum, sosial dan etika yang berlaku, (b) dewasa artinya mempunyai kemandirian untuk bertindak sebagai guru dan memiliki etos kerja sebagai guru, (c) arif dan bijaksana artinya tampilannya bermanfaat dengan menunjukkan keterbukaan dalam berfikir dan bertindak, (d) berwibawa yaitu perilaku yang disegani, (e) memiliki akhlak mulia dan perilaku yang diteladani.

Pengembangan kompetensi sosial melalui kegiatan diklat memberi bekal pada guru bagaimana cara berkomunikasi yang baik pada peserta didik maupun dengan sesama tenaga pendidik. Sebagaimana dikemukakan oleh Mulyasa (2009: 173) mengatakan kompetensi sosial guru adalah kemampuan guru sebagai bagian dari masyarakat untuk berkomunikasi dan bergaul secara efektif dengan peserta didik, sesama pendidik, tenaga pendidik, orang tua/wali peserta didik dan masyarakat sekitar.

Pengembangan kompetensi profesional melalui kegiatan diklat memberi bekal pada guru dalam menguasai teori dan teknik-teknik dalam proses pembelajaran. Sebagaimana dikemukakan oleh Daryanto (2015: 73) menekankan, bahwa guru profesional dituntut memiliki lima hal sebagai berikut: (a) mempunyai komitmen pada peserta didik dan proses belajarnya, (b) Menguasai secara mendalam bahan/materi pelajaran yang diajarkan serta cara mengajarkannya kepada para peserta didik, (c) Bertanggung jawab memantau hasil belajar peserta didik melalui berbagai teknik evaluasi, mulai cara pengamatan perilaku peserta didik sampai tes hasil belajar, (d) Mampu berpikir sistematis tentang apa yang dilakukannya dan belajar dari pengalamannya, (e) Mampu menjadi bagian dari masyarakat belajar dalam lingkungan profesionalnya.

Secara keseluruhan dapat dikemukakan bahwa SDN 22 Maros masih menerapkan kegiatan Supervisi, KKG, dan Diklat sebagai strategi yang diterapkan oleh kepala sekolah dalam mengembangkan kompetensi guru-gurunya yang pada nyatanya dapat mendukung meningkatkan kinerja guru dalam proses belajar mengajar. 


\section{Kesimpulan dan Saran}

Hasil penelitian dapat disimpulkan bahwa kompetensi pedagogic menunjukkan semua guru masuk dalam kategori tinggi, guru telah memahami dan melaksanakan kompetensi pedagogik dengan baik, kompetensi kepribadian menunjukkan semua guru masuk dalam kategori tinggi, guru telah memahami dan melaksanakan kompetensi kepribadian dengan baik, Kompetensi sosial menunjukkan terdapat delapan guru yang telah masuk dalam kategori tinggi dan enam guru yang masuk dalam kategori sedang.Kompetensi profesional, terdapat sepuluh guru yang telah masuk dalam kategori tinggi dan empat guru yang masuk dalam kategori sedang. Strategi yang digunakan kepala sekolah SDN 22 Maros dalam mengembangkan kompetensi guru ada tiga yakni melalui kegiatan Supervisi khusus, Kelompok Kerja Guru (KKG) dan Pendidikan Pelatihan (Diklat). (1) Supervisi merupakan proses pembinaan yang dilakukan kepala sekolah kepada guru-gurunya dengan mendatangi setiap kelas untuk mengobservasi bagaimana guru mengajar atau bisa dikatakan kepala sekolah ingin melihat seperti apa kekurangan dan kelemahan guru yang perlu diperbaiki agar kinerjanya dapat meningkat, (2) KKG merupakan wadah bagi guru untuk saling berbagi informasi tentang wawasan kependidikan serta sebagai tempat mencari solusi secara bersama atas permasalahan yang dihadapi selama proses belajar mengajar dikelas. Dalam kegiatan KKG ini guru membentuk kelompok kemudian membahas permasalahan secara bersama-sama. (3) (diklat) merupakan suatu kegiatan yang dilakukan untuk mengembangkan kualitas manusia utamanya guru melalui metode pengajaran dan pelatihan.

\section{Daftar Pustaka}

Andriani, Dwi Nila. 2014. Kompetensi Profesional Guru, Motivasi Belajar, Dan Gaya Belajar Berpengaruh Terhadap Pemahaman Ekonomi Siswa Kelas Xi Ips Di Sma Negeri 1 Gondang, Nganjuk. Jurnal Ekonomi Pendidikan Dan Kewirausahaan : Vol. 2. No.1, Hal 42-56.

Alsubaie, Merfat Ayesh. 2016. Curiculum Development: Teacher Involvement in Curiculum Development, Journal of Education and Practice, Vol. 7 No. 9.

Asmani, Jamal Ma'mur. 2009. Manajemen Pengelolaan dan Kepemimpinan Pendidikan Profesional. Yogyakarta: DIVA Press.

Daryanto. 2015. Guru Profesional. Yogyakarta: Gava Media.

Hidayatullah, Furqon. 2010. Pendidikan Karakter: Membangun Peradaban Bangsa. Surakarta: UNS Press\&Yuma Pustaka.

Jainuddin, J. (2019). Peningkatan Hasil Belajar Matematika Melalui Latihan Menyelesaikan Soal Secara Sistematis Pada Siswa Kelas XI. IPA1 SMA Negeri 2 Sungguminasa. Klasikal: Journal Of Education, Language Teaching And Science, 1(3), 44-52.

Jainuddin, J., \& Sirajuddin, S. (2020). Pengaruh Minat dan Kedisiplinan Siswa dengan Gaya Kognitif Field Indefendent terhadap Hasil Belajar Matematika Siswa SMK Farmasi Yamasi Makassar. Delta-Pi: Jurnal Matematika dan Pendidikan Matematika, 9(2).

Mulyasa, E. 2008. Standar Kompetensi dan Sertifikasi Guru. Bandung: PT. Remaja Rosda Karya.

Mulyasa. E. 2009. Standar Kompetensi Guru dan Sertifikasi Guru. Bandung: Remaja Rosdakarya.

Noor, Fu'ad Arif. 2015. Manajemen Guru Raudlatul Athfal (Ra) Dalam Total Quality Management (Tqm. Jurnal Pendidikan Islam. Vol. 3, No. 1, Juni. Hal. 20-40.

Nur, Alfia Anifa. 2014. Meningkatkan Kompetensi Pedagogik Guru di SD Yayasan Mutiara Gambut. Jurnal Admnistrasi Pendidikan. Vol 2 No 1. Hal. 65-72.

Undang-Undang RI No. 14 Tahun 2005 tentang Guru dan Dosen. Jakarta: Depdiknas.

Undang-Undang RI No. 20 Tahun 2003 tentang Sistem Pendidikan Nasional. Jakarta: Depdiknas.

Peraturan Menteri Pendidikan Nasional Nomor 16 Tahun 2007 Tentang Standar Kualifikasi Akademik Dan Kompetensi Guru. Jakarta: Depdiknas.

Sardiman. 2010. Interaksi dan Motivasi Belajar Mengajar. Jakarta: Rajawali Pers.

Sanjaya, Wina. 2008. Strategi Pembelajaran Berorientasi Standar Proses Pendidikan. Jakarta: Prenada Media Group.

Shabir, M.U. 2015. Kedudukan Guru Sebagai Pendidik: (Tugas dan Tanggung Jawab, Hak dan Kewajiban, dan Kompetensi Guru). Jurnal Pendidikan. Auladuna. Vol. 2 No. 2 Desember 2015. Hal. 221-232.

Sugiyono. 2012. Metode Penelitian Kuantitatif, Kualitatif dan R\&D. Bandung: Alfabeta.

Suhandani, Deni \& Julia. (2014). Identifikasi Kompetensi Guru sebagai Cerminan Profesionalisme Tenaga Pendidik di Kabupaten Sumedang (Kajian pada Kompetensi Pedagogik).

Sukmadinata, Nana Syaodih. (2011). Metode Penelitian Pendidikan. Bandung: PT Remaja Rosdakarya.

Sutikno, M. Sobari. 2013. Belajar dan Pembelajaran: Upaya Kreatif dalam Mewujudkan Pembelajaran yang Berasil. Lombok: Holistica.

Susilowati, Indah, dkk. 2013. Pendekatan Analysis Hierarchy Process. Journal of Economics and Policy. ISSN 1979-715X. Hal $80-92$.

Suyatno. 2008. Menjelajah Pembelajaran Inofatif. Sidoarjo: Masmedia Buana Pusaka.

Wena, Made. 2010. Strategi Pembelajaran Inovatif Kontemporer. Jakarta: PT Bumi Aksara.

Yahya, Muri. 2013. Profesi Tenaga Kependidikan. Bandung: Pustaka Setia. 